\title{
ANTIBIOTIC RESISTANCE PROFILE OF COMMON UROPATHOGENS IMPLICATED IN URINARY TRACT INFECTIONS IN ROMANIA
}

\author{
RĂZVAN-COSMIN PETCA ${ }^{1 \#}$, RĂZVAN-IONUȚ POPESCU ${ }^{1 *}$, CRISTIAN MARES ${ }^{1 \#}$, AIDA \\ PETCA $^{2 *}$, CLAUDIA MEHEDINȚU ${ }^{3}$, IULIA SANDU ${ }^{1}$, NICOLETA MĂRU $^{4}$ \\ ${ }^{I}$ Department of Urology, "Prof. Dr. Th. Burghele" Clinical Hospital, "Carol Davila” University of Medicine and Pharmacy, \\ Bucharest, Romania \\ ${ }^{2}$ Department of Obstetrics and Gynaecology, Elias Emergency Hospital, "Carol Davila” University of Medicine and \\ Pharmacy, Bucharest, Romania2 \\ ${ }^{3}$ Department of Obstetrics and Gynaecology, Malaxa Clinical Hospital, "Carol Davila” University of Medicine and \\ Pharmacy, Bucharest, Romania \\ ${ }^{4}$ Department of Anatomy, "Carol Davila” University of Medicine and Pharmacy, Bucharest, Romania
}

*corresponding author: aidapetca@gmail.com

${ }^{\#}$ Authors with equal contribution

Manuscript received: June 2019

\begin{abstract}
Urinary tract infections (UTIs), the second most common type, are a healthcare problem encountered in medical practice, a major cause of morbidity with a high socio-economic impact. The aim of this retrospective study was to identify the most common uropathogens, their susceptibility and resistance to conventional therapies. We analysed the urine samples from 3896 patients and we enrolled 916 cases. Bacterial isolation and antibiotic susceptibility were made using standard methods. From the Gram-negative, E. coli was the most common identified bacteria (42.9\%) followed by Klebsiella (21.17\%) and Pseudomonas aeruginosa (4.58\%). Enterococcus was the most frequent Gram-positive bacteria (18.66\%). E. coli strains showed to have an increased resistance to levofloxacin as same as Klebsiella and Enterococcus. The continuous dynamic of uropathogens in different areas and the increasing resistance to conventional antibiotic therapies is a major contemporary health problem.
\end{abstract}

\section{Rezumat}

Infecțiile de tract urinar (ITU), a doua cauză frecventă de infecții, sunt o problemă des întâlnită în practica medicală, o cauză majoră de morbiditate, cu impact socio-economic puternic. Scopul acestui studiu restrospectiv este de a identifica cei mai frecvenți uropatogeni și de a determina rezistența acestora la tratamentele antibiotice clasice. Au fost analizate 3896 de probe dintre care au fost întregistrate 916 cazuri. Izolarea bacteriilor și sensibilitatea la antibiotic a fost realizată prin metode standard. Dintre bacteriile Gram-negative, E. coli a fost cea mai frecvent identificată bacterie (42,9\%), urmată de Klebsiella (21,17\%) și Pseudomonas aeruginosa (4,58\%). Cea mai frecvent izolată bacterie Gram-pozitivă a fost enterococcul $(18,66 \%)$. Atât E. coli cât și Klebsiella și enterococcul au prezentat rezistență crescută la levofloxacin. Dinamica permanentă a uropatogenilor în diferite regiuni teritoriale și rezistența în creștere la tratamentele antibiotice este o problemă de sănătate majoră a societății actuale pentru care sunt necesare raportări și actualizări permanente.

Keywords: urinary tract infections, antibiotic, resistance, uropathogens

\section{Introduction}

Urinary tract infections (UTIs) are a major public health problem representing the second most common infectious disease in community practice and is reported to affect up to 150 million individuals annually worldwide [39]. Only in the USA, in 2007, there were 10.5 million visits for UTIs alone, representing $1 \%$ of all ambulatory visits and around 2.5 million emergency units visits. According to these facts, the high administration of antibiotics in and outside hospital without precautions has a major socioeconomic impact and is responsible for the increasing cases of antibiotic resistance in nowadays population $[25,27]$. One of the most important problems with increasing bacterial resistance is the inappropriate administration, so it is necessary for the clinicians to know better the uropathogens they are confronting with and their susceptibility according to their territorial prevalence. It is even more useful for each hospital or clinical institution to have their own evaluation of the most frequent bacteria and antibiotics resistance to immediately observe any changes in their patterns and to manage these problems accordingly. Some studies consider that UTI is the most common cause of morbidity without age or gender distinctions [32]. Regarding gender, incidence studies suggest that the overall prevalence of UTI is higher in women, almost half of them will experience at least one episode of 
FARMACIA, 2019, Vol. 67, 6

UTIs during their lifetime and 1 out of 3 will have at least one episode by the age of 24 years [11]. UTIs refer to the presence of a microbial pathogen at any level of the urinary tract infection and it is usually classified by the infection site: urine - bacteriuria, kidney - pyelonephritis or bladder - cystitis [5, 35]. Infections that occur in genitourinary tracts that have functional or structural abnormalities such as obstruction or instrumentation are considered as "complicated", whereas infections that are diagnosed in a normal urinary tract are considered "uncomplicated". From the first use, antibiotics have revolutionized and changed the management of many clinical aspects and it appeared to be no problem until now when clinicians are facing with antibiotic resistance caused by inappropriate use, dosage, time of administration and also by their usage to control infections in horticulture or in animal husbandry [23].

The most incriminated uropathogen implicated in UTIs is Escherichia Coli, with a prevalence reaching up to $85 \%$ in some studies, followed by Klebsiella, Staphylococcus, Enterococcus and Proteus [8]. Empirical antibiotic therapy is usually used as first line therapy, before the laboratory results of urine culture are available, especially in uncomplicated infections, thus following the antimicrobial resistance pattern of the urinary pathogens in the respective area $[35,44]$. The antibiotic susceptibility is mandatory to be known, in order to ensure appropriate therapy according to the organisms that cause UTIs. Therefore, it is recommended for physicians to acknowledge more information about local susceptibility pattern of uropathogens.

However, the overusing antibiotic therapy has contributed to the emergence of resistant bacterial infections [10, $16,47]$. Thus, the aim of this study was to determine the most frequent uropathogens implicated in the aetiology of UTIs and their resistance to the most common antibiotics used to treat them in one of the largest urology department in Romania.

\section{Materials and Methods}

\section{Study design}

The present retrospective study was conducted in a tertiary centre at Clinical Hospital "Prof. Dr. Theodor Burghele" in Bucharest, Romania, between $1^{\text {st }}$ of September to $30^{\text {th }}$ of November 2018. The study design was approved by the Ethical Committee of "Prof. Dr. Theodor Burghele" Clinical Hospital. We analysed clean catch midstream urine samples from 3896 patients both hospitalized and non-hospitalized and more than $90 \%$ of them underwent urology consults, so we enrolled 916 cases with positive urine cultures. The proportion of the hospitalized versus nonhospitalized patients in the study group was about 3:1 and one of our study limitations is that we cannot specify how many patients were symptomatic or asymptomatic because we did not have access to a personal medical history for the non-hospitalized patients. We obtained for each patient sociodemographic information regarding sex, age and previous hospitalizations [34].

In "Prof. Dr. Th. Burghele" Clinical Hospital there was a rationable policy for using the antibiotics during the time of the study as well as at the present time, according to the national and European guidelines, which are updated every year.

\section{Urine samples}

The urine was collected in wide mouth sterile containers from subjects who have not received antibiotics within the previous 2 weeks and immediately processed appropriately. Urine was inoculated using standard calibrated loop delivering $0.01 \mathrm{~mL}$ on Chromogenic agar medium and Columbia $5 \%$ blood agar and incubated for $18-24 \mathrm{~h}$ at $37^{\circ} \mathrm{C}$. If a single organism was cultured at a concentration $>10^{5} \mathrm{CFU} /$ $\mathrm{mL}$, the specimen was considered positive for UTIs. If the concentration was $<10^{5} \mathrm{CFU} / \mathrm{mL}$ it was considered as non-significant or negative and represented criteria of exclusion. Biochemical characteristics, gram reactions and morphology were used to identify the bacterial pathogens from cultures [33].

Antimicrobial susceptibility

The isolated colonies were then tested for antimicrobial susceptibility using the disc diffusion technique, according to the Clinical Laboratory Standards Institute (CLSI) guidelines, on Müller Hinton agar, after a standard inoculum adjusted to 0.5 McFarland was swabbed on its surface, using the ready-made antibiotics supplied dispenser, which places 8 antibiotic discs equidistantly close to the periphery of the plate and the ninth disc in the centre. All the samples were assessed uniformly in the hospital's laboratory, which has standard accreditation ISO 151189 since 2013.

Statistical analysis

Data were analysed using Microsoft - Excel software and Statistical Package for the Social Sciences (SPSS) 22 version for Windows (IBM, Armonk, NY, United States of America). Simple descriptive statistics was applied. Frequency and percentage were calculated for certain variables.

\section{Results and Discussion}

UTIs are caused by different type of bacteria which invades the local environment, then multiply, thus causing the symptomatology. Gender prevalence of UTIs is well known higher in women due to particularly anatomic characteristics of the urinary tract such as shorter urethra, the proximity of the anus and sexual activity [5, 48]. Some studies reveal that 1 of 3 women receive specific treatment for UTIs before 24 years and about $40 \%$ to $50 \%$ develop one UTI during lifetime which leads to high economic costs [12]. In our study, most of the UTIs occurred in men 484 (52.83\%), 
FARMACIA, 2019, Vol. 67, 6

while in women there were 432 cases (47.16\%), as seen in Table I, which is different comparative with other studies [38, 41], where they were frequently diagnosed in females. This difference might be linked to the higher number of male patients admitted in our hospital, which were investigated concerning urine culture preoperatively. In both genders the highest peaks of incidences occurred in patients between 60 79 years old and the lowest between 20 - 29 years old. Recent studies consider that there is a higher incidence for UTIs ratio between female and male from 20 to 40 years which may be related to sexual activity and have a strong correlation with the predisposition of female to contact UTIs [13]. Similar to this idea, in our study there is a higher incidence for the female sex between the second and the fourth decade of life. The higher percentage of UTIs in men between 60 to 80 years may be related to the increased number of men addressing our clinic with different urologic pathologies.

Table I

UTIs in male and female patients of various age groups

\begin{tabular}{|c|c|c|}
\hline Age groups & Female & Male \\
\hline (Years) & $\mathbf{n}(\boldsymbol{\%})$ & $\mathbf{n}(\boldsymbol{\%})$ \\
\hline $18-29$ & $27(2.94 \%)$ & $5(0.54 \%)$ \\
\hline $30-39$ & $41(4.47 \%)$ & $11(1.20 \%)$ \\
\hline $40-49$ & $35(3.82 \%)$ & $21(2.29 \%)$ \\
\hline $50-59$ & $57(6.22 \%)$ & $52(5.67 \%)$ \\
\hline $60-69$ & $119(12.99 \%)$ & $149(16.26 \%)$ \\
\hline $70-79$ & $117(12.77)$ & $147(16.04 \%)$ \\
\hline$>80$ & $36(3.93 \%)$ & $99(10.80 \%)$ \\
\hline Total UTI cases: $\mathbf{9 1 6}$ & $\mathbf{4 3 2}(\mathbf{4 7 . 1 6 \% )}$ & $\mathbf{4 8 4}(\mathbf{5 2 . 8 3 \% )}$ \\
\hline
\end{tabular}

The isolated bacteria from the urine samples in our study are similar to those revealed by other studies from different countries [4] but the registered results appeared to be different, as they collected urine only from outpatients, thus the comparison with our study is not totally accurate regarding the patients target group. These differences can result from different environmental conditions, health care programs or socio-economic aspects.

At first classification between Gram negative and Gram positive bacteria, our study revealed an increased percentage of $76.41 \%$ for Gram negative and $23.58 \%$ for Gram positive microorganisms, similar results being published in serial studies [7, 17], which also considered hospital based community patients.

The most common uropathogen implicated in UTIs among patients in our clinic according to our data is E. coli $-42.90 \%$ out of the total 916 cases, as seen in Table II, results that are relatively similar to other comparative studies [2, 46], from North and Latin America which enrolled only outpatients. Comparing to other reports in North and Eastern Europe [42] where the second most common uropathogen was Enterococcus faecalis, our study finds Klebsiella spp. to overcome Enterococcus representing $21.17 \%$ and only $18.66 \%$ respectively. Regarding the incidence of the other uropathogens, there were few differences comparative to other countries in Europe as other authors from Poland [21], Norway [16] or Italy [6] suggest, or even more distant countries like North America [22] or India [28]. Most of these enrolled both hospitalized and non-hospitalized patients, similar to our study.

The fourth most common pathogen was Proteus $7.75 \%$ and it was followed by Staphylococcus spp. $4.91 \%$, which is in contrast to a study from an American Journal [30] where $90 \%$ of all coagulase-negative staphylococci cultured from urine of symptomatic patients were $S$. saprophyticus. This North American report targeted both hospital and non-hospital based community patients, which is once again similar to ours and stands as a reliable comparison. The rarest strains among patients from our clinic are those of $P$. aeruginosa $-4.58 \%$ which is less than other studies previously suggested [1]. One of the major problems reported in bacterial incidence stands from over 3 decades ago, when some findings revealed a slowly decreasing percentage of $E$. coli as principal causative agent which is replaced by Enterobacteriaceae or Enterococci [18]. This strengthens the idea that periodic monitoring and closer approach to UTIs in general population are imperative in this challenging situation.

Table II

Isolated uropathogens in male and female patients

\begin{tabular}{|c|c|c|c|}
\hline Isolated Bacteria & n (\%) & Male (\%) & Female (\%) \\
\hline \multicolumn{4}{|c|}{ Gram Negative Bacteria } \\
\hline Escherichia coli & $393(42.9 \%)$ & $165(41.98 \%)$ & $228(58.01 \%)$ \\
\hline Klebsiella spp. & $194(21.17 \%)$ & $129(66.49 \%)$ & $65(33.50 \%)$ \\
\hline Pseudomonas aeruginosa & $42(4.58 \%)$ & $29(69.04 \%)$ & $13(30.95 \%)$ \\
\hline Proteus spp. & $71(7.75 \%)$ & $44(61.97 \%)$ & $27(38.02 \%)$ \\
\hline \multicolumn{4}{|c|}{ Gram Positive Bacteria } \\
\hline Enterococcus spp. & $171(18.66 \%)$ & $95(55.55 \%)$ & $76(44.44 \%)$ \\
\hline Staphylococcus spp. & $45(4.91 \%)$ & $30(66.66 \%)$ & $15(33.33 \%)$ \\
\hline
\end{tabular}

In terms of sensitivity rates for gram negative uropathogens, the highest in vitro resistance rates of $E$. coli strains were represented by levofloxacin, followed by amoxicillin-clavulanic ac. and ceftazidime, and the highest sensitivity rates were represented by meropenem and imipenem, as shown in Table III 
and Figure 1. The resistance rates of E. coli especially for fluoroquinolones are increasing all around the world due to over prescriptions. In the United States studies suggest an important trend of resistance for norfloxacin and for all other fluoroquinolones [15]. A remarkable sensitivity of $E$. coli was also observed to fosfomycin and nitrofurantoin which correspond to the present European Guidelines as short course empirical treatment for uncomplicated cystitis. According to late studies from Australia published in 2019 [14], nitrofurantoin and fosfomycin are the "old forgotten drugs" in the battle with urinary tract infections, these "simple" antibiotics being suitable with uncomplicated lower urinary tract infections and they will prove to be a useful treatment option for community-based treatment of patients with resistant microorganisms.

Table III

In vitro antibiotic sensitivity in isolated Gram negative uropathogens

\begin{tabular}{|c|c|c|c|c|c|c|c|c|}
\hline \multirow[b]{3}{*}{ ANTIBIOTICS } & \multicolumn{8}{|c|}{ GRAM NEGATIVE ORGANISM ISOLATED $(n=700)$} \\
\hline & \multicolumn{2}{|c|}{ Escherichia coli } & \multicolumn{2}{|c|}{ Klebsiella spp. } & \multicolumn{2}{|c|}{ Pseudomonas aeruginosa } & \multicolumn{2}{|c|}{ Proteus spp. } \\
\hline & $\begin{array}{c}\mathbf{R} \\
(\mathbf{m m})\end{array}$ & $\begin{array}{c}\mathbf{S} \\
(\mathrm{mm})\end{array}$ & $\begin{array}{c}\mathbf{R} \\
(\mathbf{m m})\end{array}$ & $\begin{array}{c}\mathrm{S} \\
(\mathbf{m m})\end{array}$ & $\begin{array}{c}\mathbf{R} \\
(\mathbf{m m})\end{array}$ & $\begin{array}{c}\mathbf{S} \\
(\mathrm{mm})\end{array}$ & $\begin{array}{c}\mathbf{R} \\
(\mathbf{m m})\end{array}$ & $\begin{array}{c}\mathrm{S} \\
(\mathrm{mm})\end{array}$ \\
\hline Amikacin & 17 & 374 & 37 & 101 & 6 & 34 & 5 & 66 \\
\hline Amoxicillin-Clavulanic ac. & 94 & 295 & 101 & 86 & $\mathrm{X}$ & $\mathrm{X}$ & 23 & 44 \\
\hline Aztreonam & 39 & 347 & 65 & 123 & 7 & 34 & 6 & 62 \\
\hline Ceftazidime & 40 & 349 & 65 & 126 & 7 & 33 & 7 & 63 \\
\hline Fosfomycin & 0 & 350 & $\mathrm{X}$ & $\mathrm{X}$ & $\mathrm{X}$ & $\mathrm{X}$ & $X$ & $X$ \\
\hline Imipenem & 0 & 383 & 29 & 160 & 5 & 36 & 1 & 65 \\
\hline Levofloxacin & 128 & 257 & 65 & 123 & 14 & 27 & 13 & 54 \\
\hline Meropenem & 0 & 384 & 29 & 162 & 5 & 36 & 2 & 64 \\
\hline Nitrofurantoin & 33 & 202 & $\mathrm{X}$ & $\mathrm{X}$ & $\mathrm{X}$ & $\mathrm{X}$ & $\mathrm{X}$ & $\mathrm{X}$ \\
\hline \multicolumn{9}{|c|}{$\mathrm{S}=$ SENSITIVE; $\mathrm{R}=$ RESISTANT $; \mathrm{X}=$ NOT TESTED } \\
\hline
\end{tabular}

In our study the resistance rates of $E$. coli strains to amoxicillin and fluoroquinolones are alarming. Almost a quarter of them are resistant to amoxicillinclavulanic acid $(23.91 \%)$ and a third of them are resisted to fluoroquinolones $(32.56 \%)$, which is much higher than other studies from USA and Canada [22] or United Kingdom [45]. The North American study which involved patients from USA and Canada, was designed to detect the international pathogen incidence pattern and the emergence of resistant strains. They tested the isolates to more than 50 antimicrobial agents and they acknowledged that the most frequently pathogens were E. coli $(48.6 \%)$, Enterococcus spp. (13.7\%) and Klebsiella spp. (12\%) [22]. For Gramnegative species, they found high resistance rates among beta-lactam antimicrobial agents that were noted especially for various penicillins against $E$. coli $(37.9 \%)$ and for the cephalosporins tested against enterococci $(99.4 \%)$ [22]. These data show that high rates of antimicrobial resistance for $E$. coli are a worldwide problem.

On the other hand E. coli strains in our hospital had low resistance rates for amikacin $(4.32 \%)$ and nitrofurantoin $(8.39 \%)$, results that are similar with studies from other countries like Norway [16]. Grude et al. tested urine from 28.066 patients which fulfilled the criteria for significant bacteriuria $\left(10^{5} \mathrm{CFU} / \mathrm{mL}\right.$ urine); the study was conducted for 11 months (1 January 1997 30 November 1999) and 5.352 samples were obtained from inpatients and 22.714 were from outpatients. They reported E. coli as the most frequent microorganism $(56.7 \%)$ which was highly susceptible (> 93\%) to cefalothin, mecillinam and nitrofurantoin [16]. In our study there was no resistance to fosfomycin, therefore, they may still be effectively used to replace fluoroquinolones and amoxicillin in empirical therapy of uncomplicated lower UTIs. We also registered no resistance rates to carbapenems (imipenem and meropenem), but we do not recommend their daily use, but only in severe infections or sepsis. A reasonable resistance rate of $E$. coli was registered for cephalosporines $(10.17 \%)$, comparable with other region countries like Hungary [26], making this class of antibiotics a reasonable choice for empirical treatment. In our Western neighbour country, Hungary, Magyar et al. retrospectively analysed all urine samples from hospitalized patients from January 2014 to December 2015 and found that the five most commonly occurring bacteria were E. coli, Enterococcus faecalis, Klebsiella pneumoniae, Pseudomonas aeruginosa and Proteus mirabilis, respectively. They acknowledged that even if the resistance of $E$. coli to ciprofloxacin increased significantly from 19 to $25 \%$ in the past few years, it still remained generally low. They also concluded that cephalosporins could be a good empirical choice for the treatment of Gram-negative UTIs, but they should be avoided when MDR (multi drug resistant) bacteria are suspected [26]. 


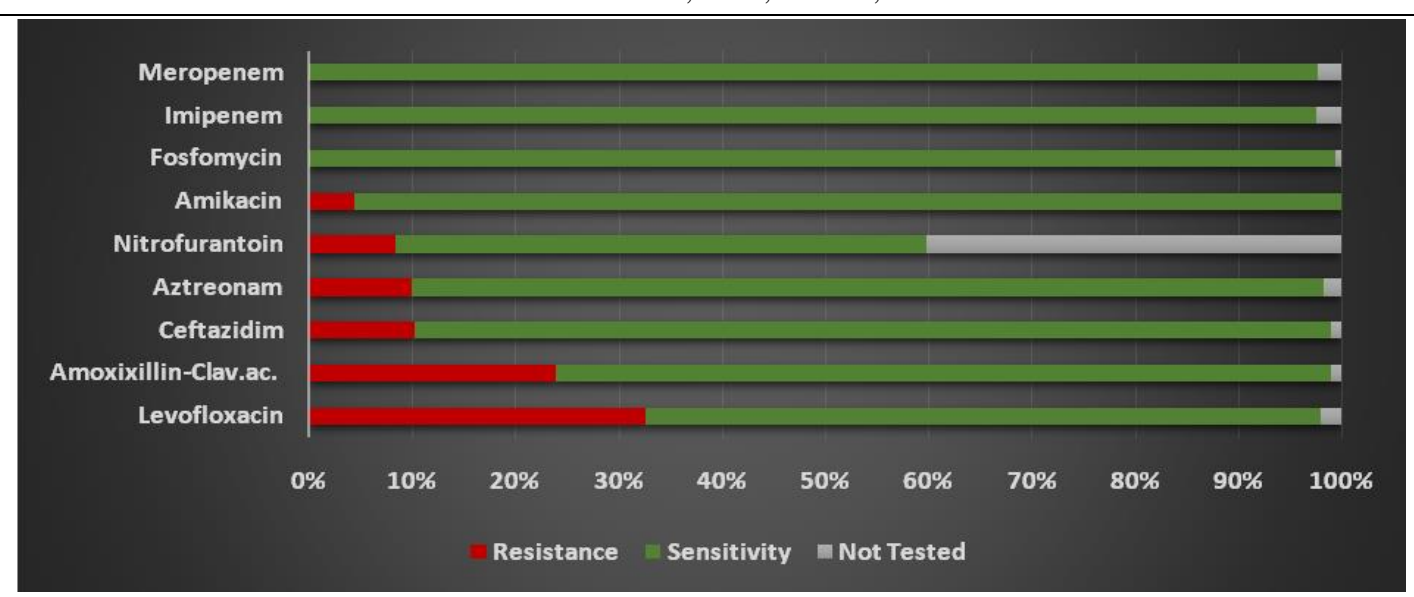

Figure 1.

Antibiotics response of E. coli strains

The highest resistance rates for Klebsiella in our study were registered for amoxicillin-clavulanic acid (Table III and Figure 2), 52.06\% of the Klebsiella strains being resistant to this drug, over used in urological infections for so many years. A remarkable aspect is that our study revealed comparable percentage of resistance rates to levofloxacin and aztreonam (34.57\%) and almost equal to ceftazidime. An alarming increased resistance rate was also observed to carbapenems, represented in our graphic by imipenem and meropenem (15.34\% and $15.18 \%$ ).

A review article written by Navon-Venezia $e t$ al. and published in 2017 [29], described Klebsiella playing a major role in the worldwide burden of antibiotic resistance. This burden is almost entirely hospitalassociated and involves epidemic strains that possess a high grade resistance that cause infections with limited treatment options, leading to increased complications and higher mortality rates and costs for the health system [3]. The same review study reported rates of ESBL production among Klebsiella hospital isolates in Israel and Spain more than $40 \%$ of the total strains and according to World Health Organization (WHO), the prevalence of ESBL-producing of Klebsiella has reached endemic rates of up to $50 \%$ in many parts of the world, and up to $30 \%$ resistance rates in the community, demonstrating one more time, the widespread of this resistance [3].

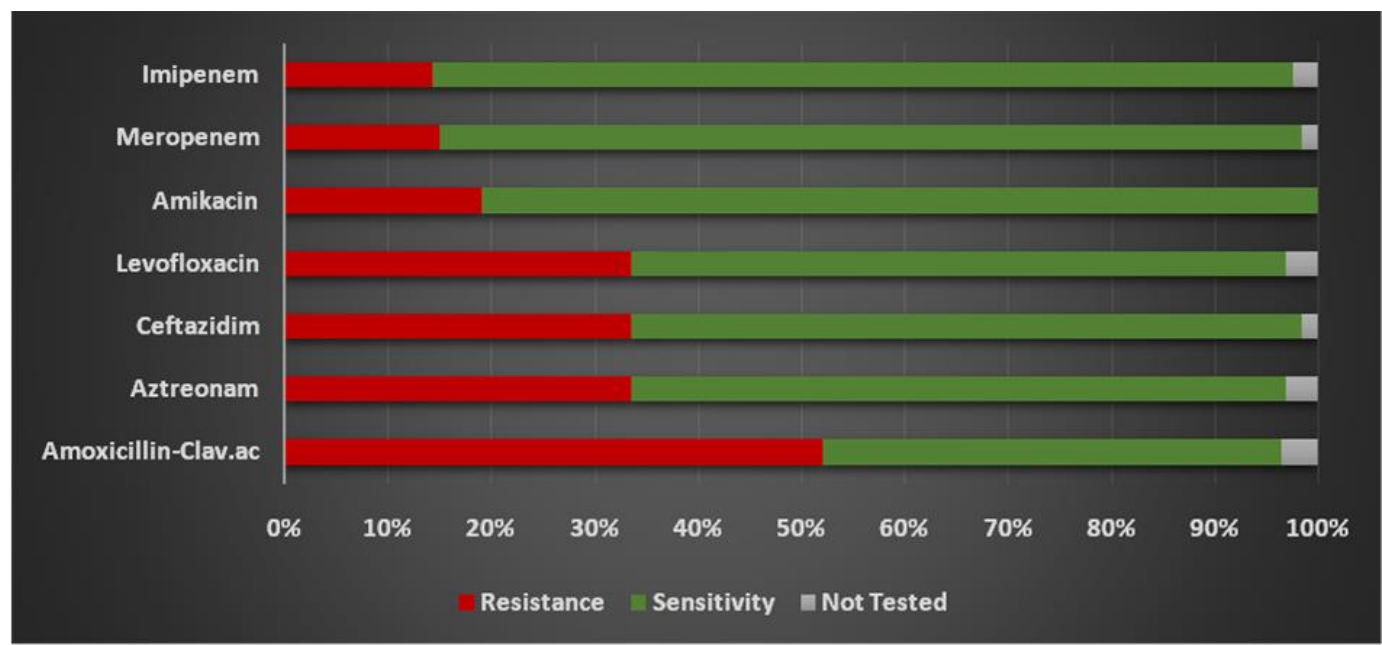

Figure 2.

Antibiotics response of Klebsiella strains

Pseudomonas was highly resistant to levofloxacin but with relatively good sensitivity rates for amikacin and ceftazidime. Proteus was also resistant to levofloxacin but with acceptable sensitivity rates for amikacin, ceftazidime and carbapenems. This data are very different comparative with other studies from North America [41], but relatively similar with other European countries like Norway [16].
Regarding the sensitivity rates of Gram positive uropathogens as seen in Table IV and Figure 3, Enterococcus spp. has high resistance rates for levofloxacin, penicillin and ampicillin and good sensitivity for fosfomycin, nitrofurantoin and linezolid. Staphylococcus aureus was also relatively resistant to penicillin, levofloxacin and trimethoprim/sulfamethoxazole but it had good response to amikacin, 
FARMACIA, 2019, Vol. 67, 6

linezolid, nitrofurantoin and ceftazidime, findings that are similar with other eastern European countries like Hungary [26]. This study didn't test the efficacy of trimethoprim-sulfamethoxazole on the enrolled patients so furthermore investigations may be considered.

In vitro antibiotic sensitivity in isolated Gram positive uropathogens

\begin{tabular}{|c|c|c|c|c|}
\hline \multirow{2}{*}{ ANTIBIOTICS } & \multicolumn{2}{|c|}{ GRAM POSITIVE ORGANISM ISOLATED $(\mathbf{n}=\mathbf{2 1 6})$} \\
\cline { 2 - 5 } & \multicolumn{2}{|c|}{ Enterococcus $\mathbf{s p p}$. } & \multicolumn{2}{c|}{ Staphylococcus spp. } \\
\cline { 2 - 5 } & $\mathbf{R}(\mathbf{m m})$ & $\mathbf{S}(\mathbf{m m})$ & $\mathbf{R}(\mathbf{m m})$ & S $(\mathbf{m m})$ \\
\hline Amikacin & $\mathrm{X}$ & $\mathrm{X}$ & 1 & 43 \\
\hline Ampicillin & 31 & 127 & $\mathrm{X}$ & $\mathrm{X}$ \\
\hline Trimethoprim/Sulfamethoxazole & $\mathrm{X}$ & $\mathrm{X}$ & 18 & 22 \\
\hline Ceftazidime & $\mathrm{X}$ & $\mathrm{X}$ & 7 & 37 \\
\hline Fosfomycin & 5 & 156 & $\mathrm{X}$ & $\mathrm{X}$ \\
\hline Levofloxacin & 68 & 100 & 19 & 23 \\
\hline Linezolid & 2 & 152 & 2 & 41 \\
\hline Nitrofurantoin & 8 & 155 & 0 & 38 \\
\hline Penicillin & 51 & 106 & 30 & 13 \\
\hline Vancomycin & 0 & 161 & $\mathrm{X}$ & $\mathrm{X}$ \\
\hline S = SENSITIVE; R = RESISTANT; X NOT TESTED \\
\hline
\end{tabular}

The susceptibility for Enterococcus showed a resistance rate of $40.47 \%$ for levofloxacin followed by penicillin $32.48 \%$ and ampicillin - $19.62 \%$ (Figure 3). Some good results were obtained with nitrofurantoin and fosfomycin which can suggest a return to some older classes of antibiotics in the era of growing resistance. The current opinion suggests the idea that nitrofurantoin and fosfomycin are good alternatives to empirically treat lower tract uncomplicated infections because many bacteria regained their sensibility. Enterococcus appeared to have no resistance to vancomycin.

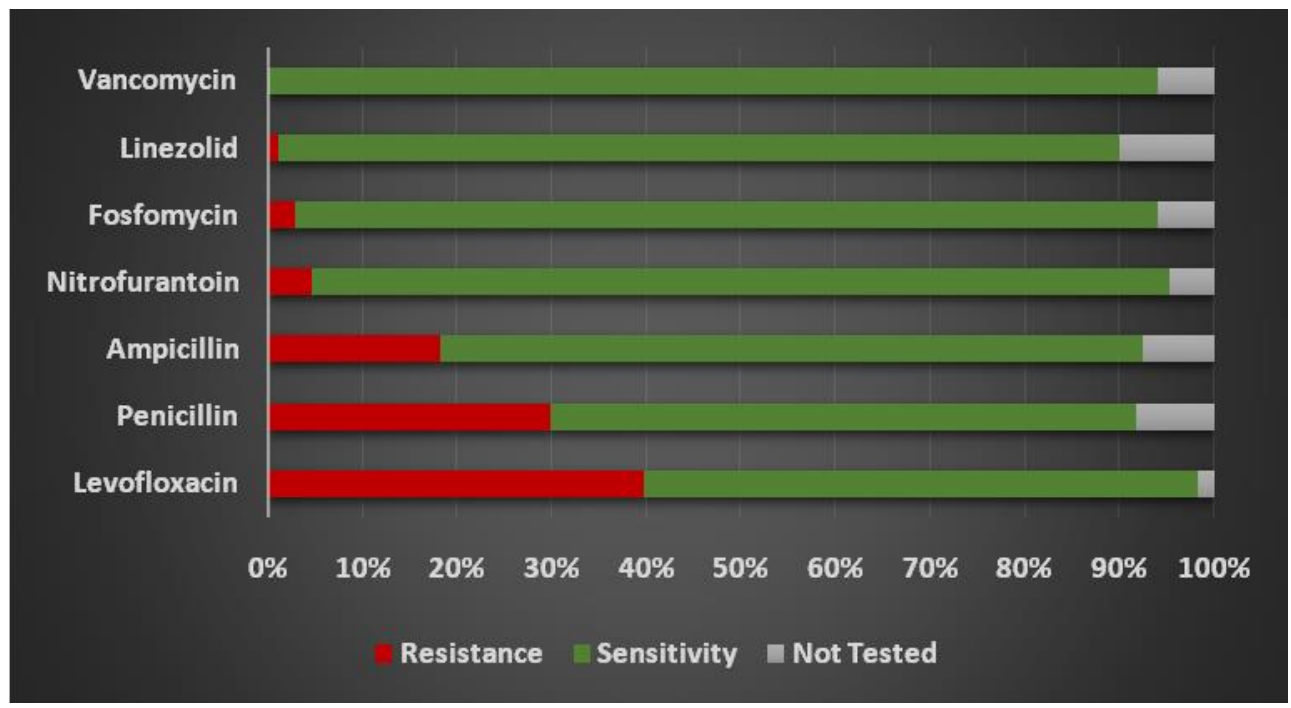

Figure 3.

Antibiotics response of Enterococcus spp. strains

As seen in Figure 3 resistance rates for fluoroquinolones are reaching alarming values, and also for penicillin and ampicillin, but on the good side, at least in our region, Enterococcus spp. involved in UTIs has, at least for now, no resistance for vancomycin. A paper in Germany, published by Remshmidt et al. in 2018 analysed data from German national nosocomial infection surveillance system for the period of 2 years (2016 - 2017) and they calculated the proportions of VRE (vancomycin resistant Enterococcus) among all nosocomial enterococcal infections [36]. Enterococcal infections from 857 Intensive Care Units (ICUs) and
1119 surgical departments were analysed and the proportion of VRE leading nosocomial infections significantly increased for UTIs from 2.9 to $9.9 \%$. They acknowledge that even if specific recommendations and efforts for prevention of nosocomial infections are implemented, transmission of VRE and improvement in drugs prescription are in place in their country, the proportion of VRE continues to significantly increase [36].

Another study in Germany, at the University Hospital of Freiburg, performed on paediatric population, conducted by Haller et al., observed relatively close 
rates of resistance of Enterococcus spp. to ampicillin, representing $15 \%$ comparing to our resistance rates of $19 \%$ [19]. The study included 261 positive urine samples analysed in 1997 and 684 from 1999 to 2001. Furthermore, we tried to determine the antimicrobial resistance rate for $E$. coli by age groups, both in men and female as it can be observed in Table $\mathrm{V}$ and Table VI. Antimicrobial resistance of urinary E. coli isolates in male population comparative to female population were almost similar and revealed an all in all increasing resistance after the age of 55. As it was expected, the highest percentages of resistance were obtained for amoxicillin-clavulanic, levofloxacin, ceftazidime, aztreonam, and nitrofurantoin. In contrast to amoxicillin-clavulanic, ceftazidime, aztreonam and nitrofurantoin whose resistances start to increase after the age of 55, levofloxacin has a higher percentage after 75 years in both male and female population. At the opposite side, all the E. coli strains which were tested were $100 \%$ percentage sensible to fosfomycin, imipenem and meropenem, at all ages. Similar results in elderly population were published in 2008 in a study on Greek population which included 2460 E. coli isolates from outpatients diagnosed with uncomplicated UTIs in 3 primary care diagnostic centres [9]. The explanation seems to be a misuse of antibiotics during lifetime.

Table V

Antimicrobial resistance of urinary $E$. coli isolates in male patients

\begin{tabular}{|c|c|c|c|c|c|}
\hline \multirow{2}{*}{ Age group (years) } & $\mathbf{3 5}$ & $\mathbf{3 5}-\mathbf{5 5}$ & $\mathbf{5 5 - 7 5}$ & $\mathbf{7 5}$ & \multicolumn{2}{c|}{ Total } \\
\cline { 2 - 6 } & \multicolumn{4}{|c|}{ Number of resistant isolates (\%) } \\
\hline Amikacin & $0(0 \%)$ & $0(0 \%)$ & $9(2.29 \%)$ & $2(0.50 \%)$ & $11(2.79 \%)$ \\
\hline Amoxicillin-clavulanic acid & $4(1.01 \%)$ & $7(1.78 \%)$ & $34(8.65 \%)$ & $13(3.30 \%)$ & $58(14.75 \%)$ \\
\hline Aztreonam & $1(0.25 \%)$ & $2(0.50 \%)$ & $19(4.83 \%)$ & $4(1.01 \%)$ & $26(6.61 \%)$ \\
\hline Ceftazidime & $0(0 \%)$ & $3(0.76 \%)$ & $16(4.07 \%)$ & $7(1.78 \%)$ & $26(6.61 \%)$ \\
\hline Fosfomycin & $0(0 \%)$ & $0(0 \%)$ & $0(0 \%)$ & $0(0 \%)$ & $0(0 \%)$ \\
\hline Imipenem & $0(0 \%)$ & $0(0 \%)$ & $0(0 \%)$ & $0(0 \%)$ & $0(0 \%)$ \\
\hline Levofloxacin & $5(1.27 \%)$ & $18(4.58 \%)$ & $20(5.08 \%)$ & $20(5.08 \%)$ & $63(16.03 \%)$ \\
\hline Meropenem & $0(0 \%)$ & $0(0 \%)$ & $0(0 \%)$ & $0(0 \%)$ & $0(0 \%)$ \\
\hline Nitrofurantoin & $1(0.25 \%)$ & $3(0.76 \%)$ & $13(3.30 \%)$ & $2(0.50 \%)$ & $19(4.83 \%)$ \\
\hline
\end{tabular}

All collected data about the bacterial incidence or antibiotic resistance based on different age ranges or sex differences are useful for clinicians in choosing the most appropriate treatment at the first presentation. Current guidelines suggest that antibiotics should be prescribed based on the local resistance patterns if there exist any deviations in the microbial incidence that is susceptible to other treatments than the general recommendations.

Antimicrobial resistance of urinary $E$. coli isolates in female patients

\begin{tabular}{|c|c|c|c|c|c|}
\hline \multirow{2}{*}{ Age group (years) } & $<\mathbf{3 5}$ & $\mathbf{3 5 - 5 5}$ & $\mathbf{5 5}-\mathbf{7 5}$ & \multicolumn{1}{|c|}{$\mathbf{7 5}$} & \multicolumn{2}{c|}{ Total } \\
\cline { 2 - 6 } & \multicolumn{4}{|c|}{ Number of resistant isolates (\%) } \\
\hline Amikacin & $0(0 \%)$ & $0(0 \%)$ & $4(1.01 \%)$ & $1(0.25 \%)$ & $5(1.27 \%)$ \\
\hline Amoxicillin-clavulanic acid & $2(0.50 \%)$ & $3(0.76 \%)$ & $24(6.10 \%)$ & $12(3.05 \%)$ & $41(10.43 \%)$ \\
\hline Aztreonam & $0(0 \%)$ & $2(0.50 \%)$ & $11(2.79 \%)$ & $4(1.01 \%)$ & $17(4.32 \%)$ \\
\hline Ceftazidime & $0(0 \%)$ & $1(0.25 \%)$ & $14(3.56 \%)$ & $2(0.50 \%)$ & $17(4.32 \%)$ \\
\hline Fosfomycin & $0(0 \%)$ & $0(0 \%)$ & $0(0 \%)$ & $0(0 \%)$ & $0(0 \%)$ \\
\hline Imipenem & $0(0 \%)$ & $0(0 \%)$ & $0(0 \%)$ & $0(0 \%)$ & $0(0 \%)$ \\
\hline Levofloxacin & $3(0.76 \%)$ & $17(4.32 \%)$ & $25(6.36 \%)$ & $20(5.08 \%)$ & $65(16.53 \%)$ \\
\hline Meropenem & $0(0 \%)$ & $0(0 \%)$ & $0(0 \%)$ & $0(0 \%)$ & $0(0 \%)$ \\
\hline Nitrofurantoin & $1(0.25 \%)$ & $2(0.50 \%)$ & $11(2.79 \%)$ & $1(0.25 \%)$ & $15(3.81 \%)$ \\
\hline
\end{tabular}

The most important aim of this study was to determine the multidrug resistance rates for each of the microbial agent involved in the most common urinary tract infections in Romania, because there are very few reports on this particular topic and none recently. After processing the data, it revealed relatively high rates of multidrug resistance, especially for $E$. coli, Klebsiella and Pseudomonas (Figure 4). Regarding the E. coli, we found $129 / 393$ strains being resistant to 1 or 2 antibiotics, 34/393 strains - 3 or 4 antibiotics, 13/393 strains - to 5 or 6 antibiotics and none of the tested strains being resisted to more than 6 antibiotics. These particular data were very similar to what Sahm et al. [37] found on their research in a study of 123.691 UTI isolates of $E$. coli, documented in The Surveillance Network Database-USA from 1 January to 30 September 2000 which were tested for at least one of the following drugs: ampicillin, cephalothin, ciprofloxacin, nitrofurantoin and sulfamethoxazole. They discovered resistance rates of $37 \%$ for 1 or 2 antibiotics, $6.9 \%$ for 3 or 4 antibiotics and $0.2 \%$ for 5 or 6 antibiotics, respectively. 
One of the most resistant microorganism in our study Klebsiella, had a relatively low profile of antimicrobial susceptibility, as $41 / 149$ being resistant to 1 or 2 drugs, 30/149 strains - to 3 or 4 drugs, 25/149 strains to 5 or 6 drugs and as many as $13 / 149$ strains being resistant to more than 6 antibiotics. These numbers are higher than what Landman et al. [24] found in 2007 in a comparative study between the years 2006,
1999 and 2000, in patients from 15 different hospitals from New York, USA. They acknowledged that the resistance rates grew from $0.1 \%$ multidrug resistance rates in 1999 , to $2.5 \%$ in 2000 and to $22 \%$ multidrug resistance rates for Klebsiella strains in 2006. They concluded that Klebsiella has clearly become the most frequent multi-drug resistant pathogen in the United States [24].

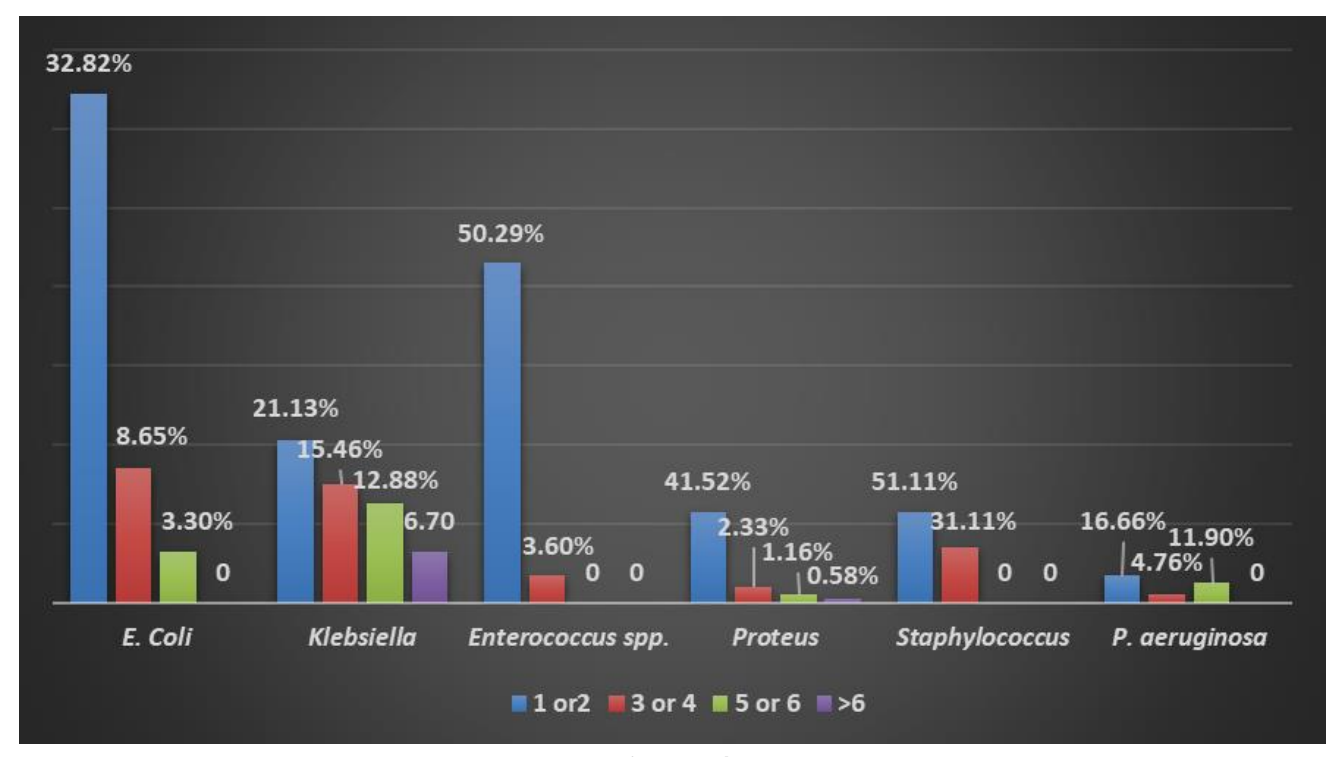

Figure 4.

Percentage of isolates showing multidrug resistance

Regarding the resistance rates of Enterococcus spp., it has relatively low rates of resistance as shown in Figure $4,86 / 171$ strains being resistant to 1 or 2 antibiotics, 7/171 strains - to 3 or 4 antibiotics and none to more than 5 drugs. These numbers are relatively good comparing to other reports, Enterococcus spp. gaining high resistance rates all around the world, especially for vancomycin, as latest data presented by O'Driscoll et al. [31] showed increasing vancomycin resistance of Enterococcus: $35.5 \%$ in the US and only $4 \%$ in Europe. They observed that enterococci are incredibly efficient in gaining resistance not only to common antibiotics but for vancomycin as well, displaying a variety of mechanisms for intrinsic and acquired resistance.

Proteus mirabilis has been known to cause serious infections but also with good antibiotic sensibility. As time passes through, the overuse of antibiotics creates "superbugs" of this microorganism, so its antibiotic resistance is continually going up. In our study we found 23/71 strains being resistant to 1 or 2 drugs, $4 / 71$ strains to 3 or 4 drugs and 3 strains to more than 5 drugs. This numbers are relatively high but lower comparing to what Tumbarello et al. [43] found in their study on 99 adult hospitalized patients from Rome's Catholic University Hospital between January 1999 and December 2009, where more than
6.6\% of the total Proteus mirabilis strains were resistant to more than 2 different antibiotics.

We found that Staphylococcus has relatively high rates of resistance for 1 or 2 antibiotics and 3 or 4 drugs, 23/45 strains and 14/25 strains respectively, but no resistance at all for more than 5 antibiotics. This data is very similar to what Styers et al. [40] presented in their work for the population of the United States in 2005. They reported that MRSA presented multi-drug resistance to ciprofloxacin, erythromycin, and clindamycin $(47.6 \%)$, double drug resistance to ciprofloxacin and erythromycin (18\%), single drug resistance to erythromycin $(13.7 \%)$, and multi-drug resistance to ciprofloxacin, erythromycin, clindamycin, and gentamicin (8.3\%) [40]. In the last few years these resistant phenotypes have been a problem for the management of inpatients.

Pseudomonas aeruginosa is an opportunistic Gramnegative bacterium that generally affects immunocompromised patients. In the last decades its rates of resistance are going up all around the world and Romania is no exception. In our study $7 / 42$ strains were resistant to 1 or 2 drugs, 2/42 strains - to 3 or 4 drugs, and 5/42strains - to 5 or 6 drugs. These numbers are high, but studies from other countries report even higher rates of resistance for this "superbug". For instance, an article from Egypt [20] reports rates of multi drug resistance of $51 \%$ for $P$. 
aeruginosa, defined as those resistant against at least three antibiotics. They concluded that $P$. aeruginosa is commonly implicated as a cause of hospital acquired infections with high mortality rates [20]. The intrinsic high mortality resistance rates to several antibiotics is the reason for the high pathogenicity of Pseudomonas, but the development of multidrug resistance in the hospital environment should also be considered.

Over the recent years, more and more studies, and also the clinicians' community, reported an increasing rate of bacterial resistance to conventional therapies derived, probably, from a misuse of antibiotics therapies over the years but the consumption remains still alarmingly high, especially in the emerging countries. The high resistance leads to a decreased number of available strategies to treat common infections and an increased use of old therapies like fosfomycin and nitrofurantoin, which can be recommended by clinicians as first line empiric agents in lower tract urinary infections according to actual European Guidelines. As many studies revealed, antibiotic resistance varies significantly in different areas, so the bacterial patterns needs a closer observation, with permanent reports, for an appropriate management according to the local pattern.

UTIs are among the most frequent diagnosed infections and affect both hospitalized and non-hospitalized persons of all ages. When diagnosed, an efficient antibiotic therapy based on high efficacy and minimum period of administration should be considered according to the current guidelines.

\section{Conclusions}

In our study, the Gram-negative isolated strains were mostly responsible for urinary tract infections and this group presented more often an increased antibiotic resistance. As it was expected, E. coli was the most common bacteria responsible for positive urine culture and it revealed an alarmingly low susceptibility for levofloxacin. High levels of resistance to levofloxacin were also found for Klebsiella, Pseudomonas and Proteus. The most effective antibiotics were carbapenems, fosfomycin and nitrofurantoin which may suggest a return to older therapies which were rarely used in recent years and probably bacteria regained their sensitivity.

In the Gram-positive group, Enterococcus, the most isolated bacteria, presented also a high resistance rate to levofloxacin. A good sensitivity was found to vancomycin, linezolid and again fosfomycin and nitrofurantoin.

As fluoroquinolones resistance rate is continuously rising, it may be prudent to limit its administration in uncomplicated infections. Uropathogens may present different sensitivity to antibiotic classes in some regions from time to time so empirical treatment for UTIs should be administrated according to the local uropathogens prevalence and their antibiotic specificity as the actual guidelines also mention.

More studies should be made on this theme, also in hospitals with a different profile, for a closer monitoring and a better understanding of the pathogens' evolution.

\section{Conflict of interest}

The authors declare that they have no potential conflicts of interest to disclose.

\section{References}

1. Al Sweih N, Jamal W, Rotimi V, Spectrum and antibiotic resistance of uropathogens isolated from hospital and community patients with urinary tract infections in two large hospitals in Kuwait. Med Princ Pract., 2005; 14(6): 401-407.

2. Andrade SS, Sader HS, Jones RN, Pereira AS, Pignatari AC, Gales AC, Increased resistance to first-line agents among bacterial pathogens isolated from urinary tract infections in Latin America: time for local guidelines? Mem Instit Oswaldo Cruz., 2006; 101(7): 741-748.

3. Antimicrobial Resistance, Global Report on Surveillance. WHO, 2014 http://www.who.int.

4. Astal ZY, Sharif FA, Relationship between demographic characteristics and community-acquired urinary tract infection. East Mediterr Health J., 2002; 8: 164-171.

5. Berceanu C, Cirstoiu M, Mehedintu C, Bratila P, Berceanu S, Vladareanu S, Bohiltea R, Bratila E, Hormone deficiency and its impact on the lower urinary tract. Proceedings of the $13^{\text {th }}$ Congress of Urogynecology (UROGYN 2016), 29 Sep - 1 Oct 2016; Brașsov, Romania: 29-38.

6. Bonadio M, Meini M, Spitaleri P, Gigli C, Current microbiological and clinical aspects of urinary tract infections. Eur J Urol., 2001; 40(4): 439-445.

7. Dorneanu R, Cioancă $\mathrm{O}$, Chifiriuc $\mathrm{O}$, Albu E, Tuchiluş C, Mircea C, Salamon I, Hăncianu M, Synergic benefits of Aronia melanocarpa anthocyanin - rich extracts and antibiotics used for urinary tract infections. Farmacia, 2017; 65(5): 778-783.

8. Dimitrov T, Udo E, Emara M, Awni F, Passadilla $\mathrm{R}$, Etiology and antibiotic susceptibility patterns of community-acquired urinary tract infections in a Kuwait hospital. Med Princ Pract., 2004; 13(6): 334-339.

9. Falagas ME, Polemis M, Alexiou VG, MariniMastrogiannaki A, Kremastinou J, Vatopoulos AC, Antimicrobial resistance of Esherichia coli urinary isolates from primary care patients in Greece. Med Sci Monit., 2008; 14(2): 75-79.

10. Ferraro MJ, Performance standards for antimicrobial disk susceptibility tests: NCCLS; 2000.

11. Foxman B, Epidemiology of urinary tract infections: incidence, morbidity, and economic costs. Dis Mon., 2003; 49(2): 53-70.

12. Foxman B, Epidemiology of urinary tract infections: incidence, morbidity, and economic costs. Am J Med., 2002; 113(1): 5-13.

13. Gales AC, Jones RN, Gordon KA, Sader HS, Wilke WW, Beach ML, Pfaller MA, Doern GV, Activity and spectrum of 22 antimicrobial agents tested against urinary tract infection pathogens in hospitalized patients in Latin America: report from the second year of the 
SENTRY antimicrobial surveillance program (1998). J Antimicrob Chemother., 2000; 45(3): 295-303.

14. Gardiner BJ, Stewardson AJ, Abbott IJ, Peleg AY, Nitrofurantoin and fosfomycin for resistant urinary tract infections: old drugs for emerging problems. Aust Prescr., 2019; 42(1): 14-19.

15. Goettsch W, van Pelt W, Nagelkerke N, Hendrix M, Buiting A, Petit P, Sabbe LJ, van Griethuysen AJ, de Neeling AJ, Increasing resistance to fluoroquinolones in Escherichia coli from urinary tract infections in the Netherlands. J Antimicrob Chemother., 2000; 46(2): 223-228.

16. Grude N, Tveten $Y$, Kristiansen BE, Urinary tract infections in Norway: bacterial etiology and susceptibility. A retrospective study of clinical isolates. Clin Microbiol Infect., 2001; 7(10): 543-547.

17. Grüneberg R, Antibiotic sensitivities of urinary pathogens, 1971-1978. J Clin Pathol., 1980; 33(9): 853-856.

18. Grüneberg R, Changes in urinary pathogens and their antibiotic sensitivities, 1971-1992. J Antimicrob Chemother., 1994; 33(suppl_A): 1-8.

19. Haller M, Brandis M, Berner R, Antibiotic resistance of urinary tract pathogens and rationale for empirical intravenous therapy. Pediatr Nephrol., 2004; 19(9): 982-986.

20. Hassuna NA, Mohamed AHI, Abo-Eleuoon SM, Rizk HA-WA, High Prevalence of Multidrug Resistant Pseudomonas aeruginosa recovered from infected burn wounds in children. Arch Clin Microbiol., 2015; 6(4): $1-7$

21. Hryniewicz K, Szczypa K, Sulikowska A, Jankowski K, Betlejewska K, Hryniewicz W, Antibiotic susceptibility of bacterial strains isolated from urinary tract infections in Poland. J Antimicrob Chemother., 2001; 47(6): 773-780.

22. Jones RN, Kugler KC, Pfaller MA, Winokur PL, Characteristics of pathogens causing urinary tract infections in hospitals in North America: results from the SENTRY Antimicrobial Surveillance Program, 1997. Diagn Microbiol Infect Dis., 1999; 35(1): 55-63.

23. Kerr JR, Antibiotic treatment and susceptibility testing. J Clin Pathol., 2005, 58(8): 786-787.

24. Landman D, Bratu S, Kochar S, Panwar M, Trehan M, Doymaz M, Quale J, Evolution of antimicrobial resistance among Pseudomonas aeruginosa, Acinetobacter baumannii and Klebsiella pneumoniae in Brooklyn, NY. J Antimicrob Chemother., 2007; 60(1): 78-82.

25. Magee J, Pritchard EL, Fitzgerald KA, Dunstan F, Howard A, Antibiotic prescribing and antibiotic resistance in community practice: retrospective study, 1996-8. BMJ., 1999; 319(7219): 1239-1240.

26. Magyar A, Köves B, Nagy K, Dobák A, Arthanareeswaran VKA, Bálint P, Wagenlehner F, Tenke P, Spectrum and antibiotic resistance of uropathogens between 2004 and 2015 in a tertiary care hospital in Hungary. J Med Microbiol., 2017; 66(6): 788-797.

27. Mobley HL, Virulence of the Two Primary Uropathogens Escherichia coli and Proteus mirabilis exhibit distinct mechanisms of pathogenesis when causing urinary tract infections. ASM News., 2000; 66(7): 403-410.

28. Navaneeth B, Belwadi S, Suganthi N, Urinary pathogens' resistance to common antibiotics: a retrospective analysis. Trop Doct., 2002; 32(1): 20-22.
29. Navon-Venezia S, Kondratyeva K, Carattoli A, Klebsiella pneumoniae: a major worldwide source and shuttle for antibiotic resistance. FEMS Microbiol Rev., 2017; 41(3): 252-275.

30. Nicolle L, Hoban S, Harding G, Characterization of coagulase-negative staphylococci from urinary tract specimens. J Clin Microbiol., 1983; 17(2): 267-271.

31. O'Driscoll T, Crank CW, Vancomycin-resistant enterococcal infections: epidemiology, clinical manifestations, and optimal management. Infect Drug Resist., 2015; 8: 217-230.

32. Omoregie R, Erebor JO, Ahonkhai I, Isibor JO, Ogefere HO, Observed changes in the prevalence of uropathogens in Benin City, Nigeria. NZJ Med Lab Sci., 2008; 62(2): 29-31.

33. Petca A, Radu DC, Petca RC, Mehedintu C, Barac RI, Ionescu A, Dogaroiu C, Berceanu C, Maru, N, Current trends of liquid chromatography tandem mass spectroscopy use in clinical gynecology. Rev Chim (Bucharest), 2019; 70(6): 2021-2025.

34. Petca RC, Mares C, Popescu R, Petca A, Diaconescu $\mathrm{D}$, Braticevici B, Jinga V. Antibiotic resistance profile of uropathogens strains implicated in the etiology of the urinary tract infections. Eur Urol Suppl., 2019; 18(2): e2397.

35. Petca RC, Popescu RI, Mehedințu C, Boț M, Veduța A, Petca A, The role of ultrasound in diagnosis and management in renal colic during pregnancy. Proceedings of the $6^{\text {th }}$ Congress of the Ultrasound Society in Obstetrics and Gynecology / $34^{\text {th }}$ Fetus as a Patient International Congress, 16 - 19 May 2018; Bucharest, Romania: 478-484.

36. Remschmidt C, Schröder C, Behnke M, Gastmeier P, Geffers C, Kramer TS, Continuous increase of vancomycin resistance in enterococci causing nosocomial infections in Germany - 10 years of surveillance. Antimicrob Resist Infect Control., 2018; 7(1): 1-7.

37. Sahm DF, Thornsberry C, Mayfield DC, Jones ME, Karlowsky JA, Multidrug-Resistant Urinary Tract Isolates ofEscherichia coli: Prevalence and Patient Demographics in the United States in 2000. Antimicrob Agents Chemother., 2001; 45(5): 1402-1406.

38. Schaeffer AJ, Rajan N, Cao Q, Anderson B, Pruden DL, Sensibar J, Duncan JL, Host pathogenesis in urinary tract infections. Int J Antimicrob Agents., 2001; 17(4): 245-251.

39. Stamm WE, Norrby SR, Urinary tract infections: disease panorama and challenges. J Infect Dis., 2001; 183(Supplement_1): S1-S4.

40. Styers D, Sheehan DJ, Hogan P, Sahm DF, Laboratory-based surveillance of current antimicrobial resistance patterns and trends among Staphylococcus aureus: 2005 status in the United States. Ann Clin Microbiol Antimicrob., 2006; 5(1): 1-9.

41. Tambekar D, Dhanorkar D, Gulhane S, Khandelwal V, Dudhane M, Antibacterial susceptibility of some urinary tract pathogens to commonly used antibiotics. Afr J Biotechnol., 2006; 5(17): 1562-1565.

42. Tandogdu Z, Cek M, Wagenlehner F, Naber K, Tenke $\mathrm{P}$, van Ostrum E, Johansen TEB, Resistance patterns of nosocomial urinary tract infections in urology departments: 8-year results of the global prevalence of infections in urology study. World J Urol., 2014; 32(3): 791-801. 
43. Tumbarello M, Trecarichi EM, Fiori B, Losito AR, D'Inzeo T, Campana L, Ruggeri A, Di Meco E, Liberto E, Fadda G, Cauda R, Spanu T, Multidrugresistant Proteus mirabilis bloodstream infections: risk factors and outcomes. Antimicrob Agents Chemother., 2012; 56(6): 3224-3231.

44. Wilson ML, Gaido L, Laboratory diagnosis of urinary tract infections in adult patients. Clin Infect Dis., 2004; 38(8): 1150-1158.

45. Winstanley T, Limb D, Eggington R, Hancock F, A 10 year survey of the antimicrobial susceptibility of urinary tract isolates in the UK: the Microbe Base project. J Antimicrob Chemother., 1997; 40(4): 591594.

46. Zhanel GG, Hisanaga TL, Laing NM, DeCorby MR, Nichol KA, Palatnick LP, Johnson J, Noreddin A,
Harding GK, Nicolle LE, Hoban DJ; NAUTICA Group, Antibiotic resistance in outpatient urinary isolates: final results from the North American Urinary Tract Infection Collaborative Alliance (NAUTICA). Int J Antimicrob Agents., 2005; 26(5): 380-388.

47. Voicu M, Cristescu C, Zbârcea CE, Voicu A, Buda V, Suciu L, Suciu M, Proks M, Bild V, Comparative study of antimicrobials use and the antibiotic resistance of Gram negative strains. Farmacia, 2017; 65(2): 225-229.

48. Zvanca ME, Bot M, Radu D, Radu N, Petca A, Impact of early supplementation with low-dose aspirin on functional first trimester parameters in low-risk pregnancies. J Matern Fetal Neonatal Med., 2019; 32(4): 604-609. 